\title{
An Overview of the Impacts of Land Use Land Cover Changes (1980-2014) on Urban Water Security of Kolkata
}

\author{
Subham Mukherjee *, Wiebke Bebermeier and Brigitta Schütt \\ Department of Physical Geography, Institute of Geographical Sciences, Freie Universität Berlin, Malteserstr. \\ 74-100, 12249 Berlin, Germany; wiebke.bebermeier@fu-berlin.de (W.B.); Brigitta.Schuett@fu-berlin.de (B.S.) \\ * Correspondence: subham.m@fu-berlin.de; Tel.: +49-17622589370
}

Received: 13 June 2018; Accepted: 27 July 2018; Published: 30 July 2018

\begin{abstract}
Urban Water Security is essential in urban planning to manage cities' water infrastructures and strengthen their water stress resilience and adaptive capacities. Decision making, governance and socio-economic factors play important roles in achieving Urban Water Security. Kolkata is a growing megacity in a developing country, which is facing rising pressures on water-environmental provisions due to the rapid population growth and urbanization and resultant governance and infrastructural issues. This review focusses on Kolkata, which is facing critical water issues, as a case study. The study presents an overview of the urban water (in)security and its dimensions in Kolkata city, such as water consumption and distribution in the city along with the changing land use-land cover of the city area, based on the results obtained from the satellite data-based land use-land cover classification, available literature, and documents from public institutions.
\end{abstract}

Keywords: population growth; land use-land cover; image classification; change detection; water security

\section{Introduction}

Urbanization is a human-induced process and results in land use-land cover (LULC) change and concurrent alteration of the quantity and quality of surface and groundwater resources especially in the peri-urban areas [1,2]. Land use is a combined result of human activities and natural factors. Land cover, on the other hand, is either natural or the effects of land use changes due to, especially, human activities [3,4]. Changing societal needs and priorities come along with the growing number of people and housing densities [2,5] and in turn affect the environment [1]. Unplanned urbanization results in sprawled regions within and outside of the city centers; these areas usually lack basic infrastructure such as treated water supply, sanitation, and electricity [5,6]. In consequence, the resulting water insecurity in the urban and peri-urban areas is either triggered directly by population increase, demand-supply problems, problems regarding surface water bodies and availability, problems in slums regarding sanitation and hygiene or indirectly by the environmental risk related issues (such as floods) and preconditions (such as shrinkages of surface water bodies, impervious surface effect on groundwater recharge, and urban heat islands) [7].

"Water Security" is a conceptualized term, which ensures every citizen with the amount of quality water required for his or her everyday life [8]. There is no universal definition (neither measurement index) of Water Security as it varies with approaches and perceived with a different set of goals it deals with. There is, rather, a range of published definitions of water security by different government, non-government agencies, and scholars to date. Every definition is different from each other, but there are a few common factors that integrate all of them. These are the goals that drive the approach to 
reach water security in a region. The concept of urban water security emphasizes the availability and accessibility of safe and enough water without harming the sustainability of ecosystems, focusing on reducing the probability or risk of ecological disaster caused by human-induced stresses. Therefore, in this article we adapted the Sustainable Development Goal 6, which refers to clean, accessible water for all; however, the right to water security entitles everyone to sufficient, safe, acceptable, physically accessible and affordable water for domestic uses [9]. Since the issues are huge and requires individual attention to the details, for this article, the discussion is based on only three broader aspects; i.e., water demand and supply, accessibility and the risks associated with flood, water-borne diseases, and waste management- to get an overview of the study area in terms of water security. Water insecurity in urbanized areas in general is based on various socio-economic factors: next to uncontrolled population growth, for example, it is based on poor governance and mismanagement of the water supply system. Parallel, physical processes like climate change must be considered as a catalyst. To establish a sustainable urban water management system characters such as the ratio between availability and required amount of drinking water supply, physical and virtual water demand, and the supply of water are the major components that need to be considered.

New or newly emerging countries can be characterized as being in a dearth of financial potentiality to mitigate water-environmental issues. The most number of people who are affected by water related problems in urban areas, such as water scarcity of required quality water, live in emerging countries [10]. Gaps between national and regional policies for water result in the lack of efficient management plans. In consequence, management decisions regarding purification, distribution, and extraction facilities, and to reduce problems associated to sewage disposal and related threats to the downstream areas, are deficient due to missing governance structures [11].

Kolkata is the capital of West Bengal state of India. Core Kolkata city spreads over around $200 \mathrm{~km}^{2}$ and has a population of 4.5 million people. The greater urban area includes 41 other cities and hosts nearly 15 million inhabitants, making it the third largest city area in India. Since 1690, the approximate year when the British founded Kolkata, it has been expanding randomly without having a proper master plan [12]. Besides, Kolkata is blessed ecologically because it has, "the Ganga flowing beside its western end, traditionally huge groundwater reserve and wide wetlands area in its eastern fringe which naturally treats its waste water and turns that as raw water for fishery and agriculture." [13]. Despite these advantages, the city is at present increasingly running into water insecurity.

The Ganga river system contributes significantly towards the transport of pollutants to the coastal areas of the Bay of Bengal [14,15]. The river's poor surface water quality is closely related to its insufficient waste water treatment facilities [16,17]. In consequence, waterborne diseases are still an important issue to deal with [14]. Beyond, Kolkata has recently received the 'extreme risk' tag as it ranks 7th on the global list of cities most vulnerable to climate change [18]. It is assumed that until 2025 Kolkata frequently will be hit by storms, cyclones, and hurricanes alongside extreme temperature and rainfall events. These weather extreme events will affect directly the existing water-environment and socio-economic activities, bringing risks to human health and eco-system health $[16,19]$.

In this article, the linkages between LULC change and urban water security are explored for the Kolkata Municipal Corporation (KMC) area. The focus is set on uncontrolled urbanization processes and insufficient water management practices, which have their resultant combined effects on water insecurity within the KMC area. Building on land use-land cover change detections and a literature survey, the dynamic linkage between land use-land cover change and urban water security is overviewed. The local scale of urban water security problems within the KMC area caused by land use-land cover changes over the last four decades and the resulting impacts (direct and indirect) on the existing infrastructure are addressed through the review of scientific literature and reports. 


\section{Study Area}

The study area encompasses the Kolkata Municipal Corporation area (KMC), located at the left (eastern) bank of the river Hooghly in the western Ganga delta (Figure 1; $22^{\circ} 28^{\prime} 00^{\prime \prime}-22^{\circ} 37^{\prime} 30^{\prime \prime} \mathrm{N}$ $88^{\circ} 17^{\prime} 30^{\prime \prime}-88^{\circ} 25^{\prime} 00^{\prime \prime} \mathrm{E}$ ). The climate of Kolkata is a tropical wet-and-dry climate (Aw according to Köppen climate classification system). The city experiences a hot pre-monsoon season from late March to mid-June followed by a monsoon period from mid-June till mid-September and lastly a slightly cooler dry season from mid-October until mid-March [20]. The annual temperature averages 26.8 ${ }^{\circ} \mathrm{C}$ with monthly mean temperatures ranging from $19{ }^{\circ} \mathrm{C}$ in January to $30^{\circ} \mathrm{C}$ in May [18]. The hot pre-monsoon season in Kolkata is windy in the afternoon and often characterized by violent dust storms that are brought by the convective 'Kal Baishakhi' winds (Nor'westers), accompanied by spells of thunderstorms or hailstorms and heavy rains with ice pellets or sleets. During late pre-monsoon season (May and June) maximum temperature rises to $38^{\circ} \mathrm{C}$. The Monsoon season is characterized by heavy rainfall, which especially is expected in August (monthly average $306 \mathrm{~mm}$ ). The annual rainfall averages $1582 \mathrm{~mm}$ (1971-2010), comprising average monsoon rainfalls of $1182 \mathrm{~mm}$ (1971-2010) and average non-monsoon rainfall of $365 \mathrm{~mm}$ (1971-2010) [21]. The annual sunshine hours in Kolkata average $2528 \mathrm{~h}$ (1971-2010) with the maximum number of sunshine hours occurring in March. Kolkata is located approximately $150 \mathrm{~km}$ upcountry from the Bay of Bengal coast, which is still under the influence of sea wind movement and close enough to make it highly humid corresponding to air moisture [20].

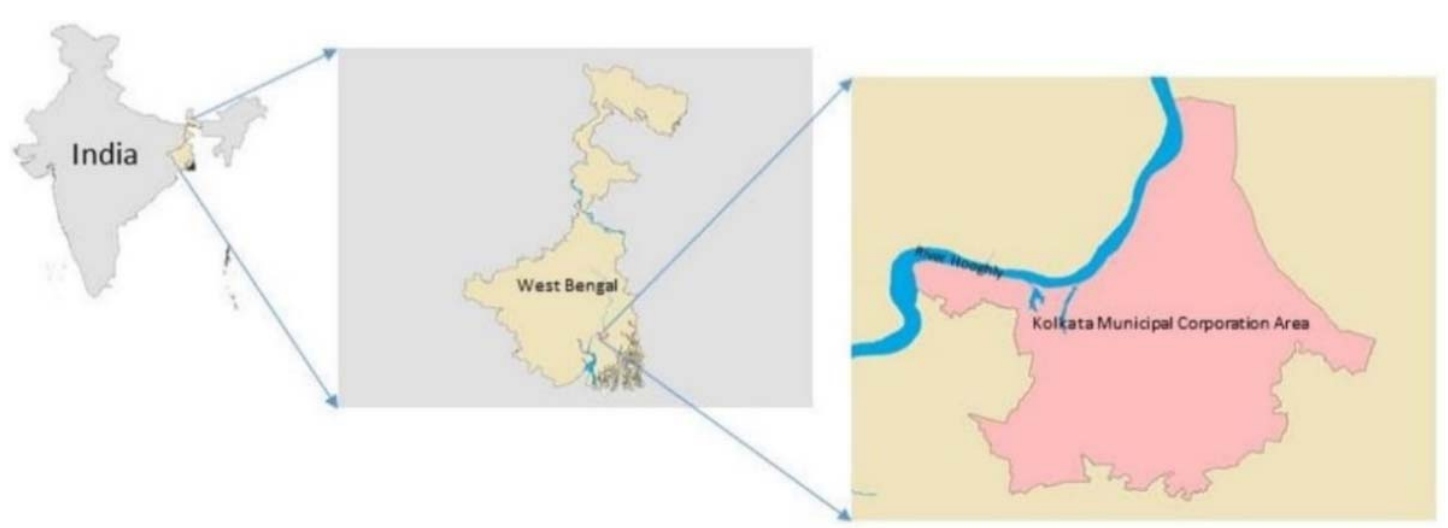

Figure 1. Location of Kolkata Municipal Corporation area (Source: Kolkata Municipal Corporation, 2016).

Kolkata Municipal Corporation area $\left(\mathrm{KMC}\right.$, area $\left.205 \mathrm{Km}^{2}\right)$ forms the centroid of the Kolkata Metropolitan Area (KMA, area $1886.67 \mathrm{Km}^{2}$ ) and corresponds to the urban agglomeration of the city of Kolkata (Figure 2). KMC currently is composed of 144 (including the newly added three) wards, which are grouped into 16 boroughs or administrative blocks (Table 1; Figure 3) having 21 assemblies and 3 parliamentary constituencies. Within the KMC area no so-called "big industry" occurs; the majority is small scale industries that are mostly spread along the banks of the river Hooghly. The Kolkata industrial hub is a major market in eastern India. The Kolkata port functions as a major entry point for neighboring countries like Nepal, Bangladesh, and Bhutan as well as for northeast India. 


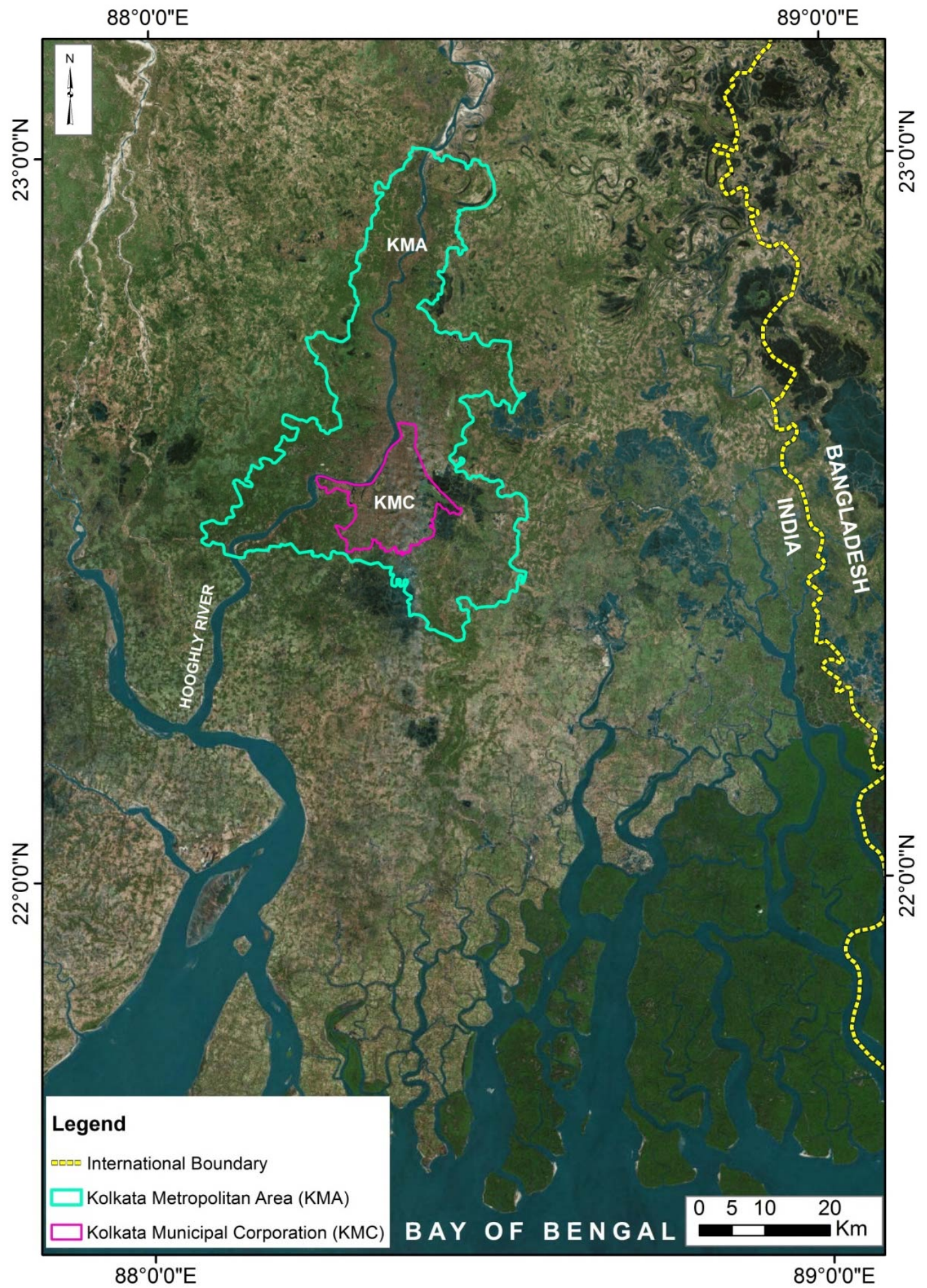

Figure 2. Map showing Kolkata Municipal Corporation area (KMC) and Kolkata Metropolitan Area (KMA) located within the vicinity of the coast and close to the international border of Bangladesh (Source: Kolkata Municipal Corporation, 2017, Google Map: Google Corporation Pvt Ltd, California, CA, United States., 2018). 
Table 1. List of Boroughs and the associated wards of the Kolkata Municipal Corporation (KMC); (excluding the newly added three wards until 2016 annual report published by KMC; Kolkata Municipal Corporation, 2016).

\begin{tabular}{cc}
\hline Borough & Ward No. \\
\hline I & $1,2,3,4,5,6,7,8 \& 9$ \\
II & $10,11,12,15,16,17,18,19 \& 20$ \\
III & $13,14,29,30,31,32,33,34 \& 35$ \\
IV & $21,22,23,24,25,26,27,28,38 \& 39$ \\
V & $36,37,40,41,42,43,44,45,48,49 \& 50$ \\
VI & $46,47,51,52,53,54,55,60,61 \& 62$ \\
VII & $56,57,58,59,63,64,65,66 \& 67$ \\
VIII & $68,69,70,72,83,84,85,86,87,88 \& 90$ \\
IX & $71,73,74,75,76,77,78,79,80 \& 82$ \\
X & $81,89,91,92,93,94,95,96,97,98,99 \& 100$ \\
XI & $103,104,110,111,112,113 \& 114$ \\
XII & $101,102,105,106,107,108 \& 109$ \\
XIII & $115,116,117,118,119,120 \& 122$ \\
XIV & $121,127,128,129,130,131 \& 132$ \\
XV & $123,124,125,126$ \\
XVI & $133,134,135,136,137,138,139,140 \& 141$ \\
\hline
\end{tabular}

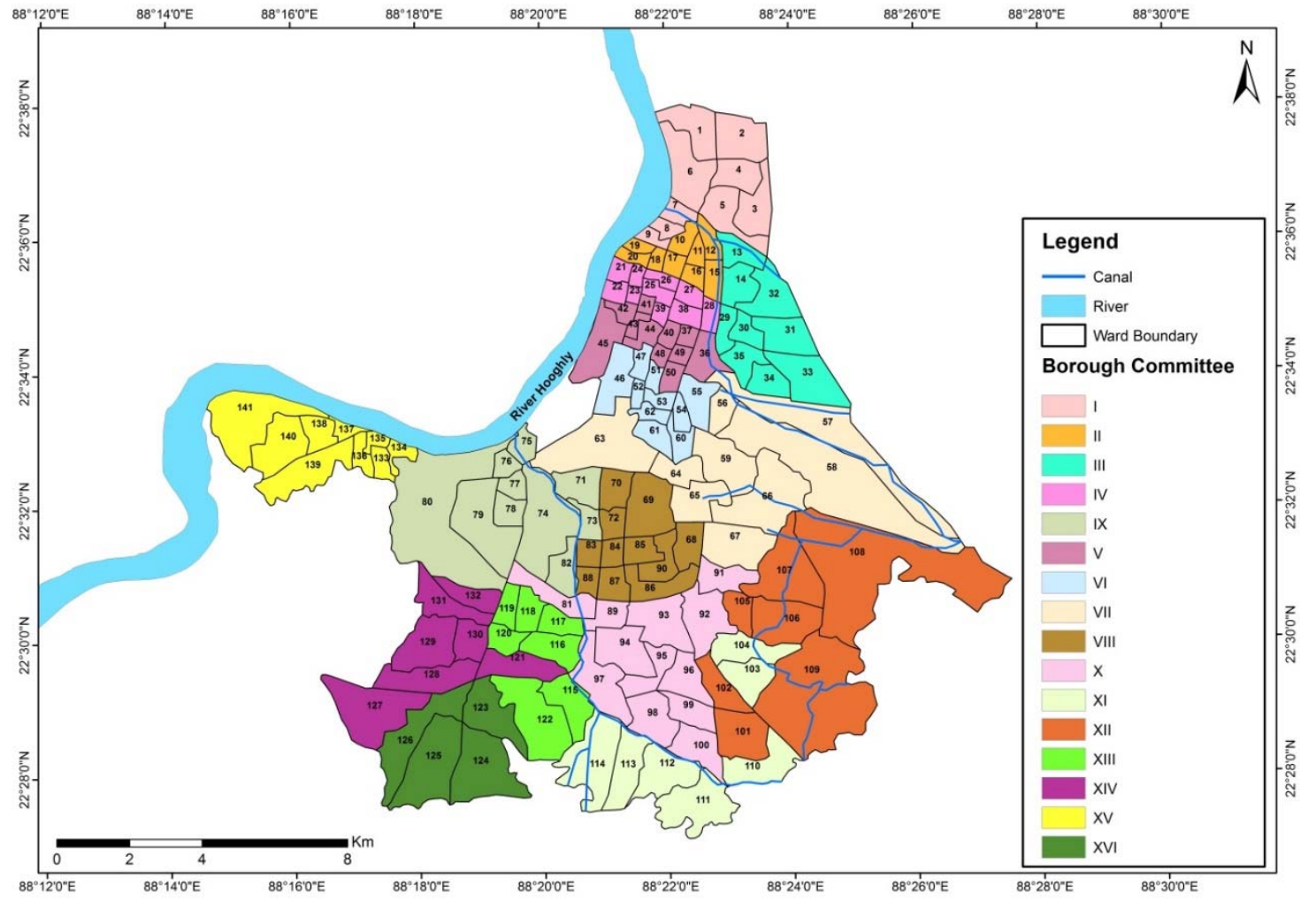

Figure 3. Borough Map of Kolkata Municipal Corporation area featuring all the associated wards for each borough (source: Kolkata Municipal Corporation, 2016).

Kolkata Municipal Corporation is in the lower deltaic plains of the Ganga-Bhagirthi-Hooghly river system; i.e., the southern (Indian) part of Ganga-Brahmaputra Delta. The down-stream channel of Bhagirathi Channel in the tidal stretch is called Hooghly. The elevations in this area range between 3.5 to $6.0 \mathrm{~m}$ above mean sea level (amsl) and relief is flat [22]. Locally low-lying depressions such as marshes and shallow lakes (Jhils) occur within the deltaic plain. Most of these formations represent paleo-river channels of the Bhagirathi. The main slope of the surface dips towards the south. Levees, 
inter-distributary marsh, and paleo-channels are the most important geomorphological features in the deltaic plain. The Hooghly River and several canals like Bagjola Khal (canal) in the north and Beleiaghata and Circular Khal (canal) in the central part and Adi-Ganga canal along with Talli nala (canal) in the southern part of the city drain the area. Presently these waterbodies are largely silted.

The details of the Water Statistics of Kolkata Municipal Corporation (KMC) area are compiled in Table 2. The data are primarily based on Census of India [23,24].

Table 2. Water Statistics of Kolkata Municipal Corporation (KMC) [12,23-27].

\begin{tabular}{|c|c|}
\hline \multicolumn{2}{|l|}{ Demography } \\
\hline Kolkata Municipal Corporation (KMC) Area (2011) & $205 \mathrm{Km}^{2}$ \\
\hline Population & $4,496,694$ \\
\hline Floating Population & 6,000,000 Per Day \\
\hline Total Water Demand (based on KMC) & 925 MLD (as per KMC); 952 (as per CPHEEO) \\
\hline Per Capita Demand & $170 \mathrm{MLD}$ \\
\hline \multicolumn{2}{|l|}{ Water Supply System } \\
\hline Sources & Hooghly River and groundwater from deep and hand tube-wells \\
\hline Surface Water Contribution & $89 \%$ \\
\hline Groundwater Contribution & $11 \%$ \\
\hline Total Water Supplied & 1216 MLD \\
\hline Per Capita Supplied & $224 \mathrm{LPCD}$ \\
\hline Loss due to Leakage & $35 \%$ \\
\hline Actual Supply (After Loss) & 790 MLD \\
\hline Per Capita Supply (After Loss) & $145 \%$ \\
\hline Population served by Water Supply System & $92 \%$ [27]; 85\% [12] \\
\hline Per Capita Water Supply Served & 134 LPCD [24]; 171 LPCD [12] \\
\hline Demand-Supply Gap (After Loss) & 135 MLD \\
\hline Continuity of Water Supplied (in Hours) & 8 \\
\hline Residual Pressure & 3.6 PSI \\
\hline Number of Water Treatment Plants & 4 \\
\hline Designed Capacity for water Production & 1787 MLD \\
\hline Actual Capacity & 1080 MLD \\
\hline Operational Capacity for Surface Water Production & $1260 \mathrm{MLD}$ \\
\hline Operational Capacity for Ground Water Production & 114 MLD \\
\hline Reservoir Capacity & $256 \mathrm{ML}$ \\
\hline Hand Tube-wells & 12,000 \\
\hline Large Tube-wells & 400 \\
\hline Water Supply Distribution Pipes & $5687 \mathrm{Km}$ \\
\hline Number of Piped Connections & 245,019 [27] \\
\hline Household with access to water & $79 \%$ \\
\hline Water Price for Domestic Usage & $\begin{array}{l}\text { Unbilled for up to one connection/premise additional water supply: } \\
\text { US } \$ 0.15 / \mathrm{m}^{3}\end{array}$ \\
\hline $\begin{array}{l}\text { Water Price for Commercial, Industrial and } \\
\text { Institutional Usage }\end{array}$ & $\begin{array}{l}\text { Flat-rate between US } \$ 11.6 \text { and US } \$ 66 \text { (Monthly) Additional Water } \\
\text { Supply: US } \$ 0.33 / \mathrm{m}^{3}\end{array}$ \\
\hline
\end{tabular}

\section{Data and Methods}

\subsection{Data}

The study is primarily based on a literature review and analysis of secondary data from various sources including data bases available at the Kolkata Municipal Corporation. In addition, satellite images were analyzed to detect changes of the distribution of the major land cover classes surface water bodies, building area, and vegetated area since 1980 in ten-year time steps. Satellite images with their Date of Acquisition (DoA) applied are: 
(1) Landsat Multispectral Scanner (MSS) image (path 148, rows 44 and 45) DoA: 16 January 1980;

(2) Landsat Thematic Mapper (TM) image (path 138, row 44) DoA: 14 November 1990;

(3) Landsat Enhanced Thematic Mapper Plus (ETM+) image (path 138, row 44) DoA: 17 November 2000;

(4) Indian Remote Sensing (IRS) Resourcesat-1 Linear Imaging Self-Scanning Sensor (LISS) III image (path 108, row 56) DoA: 3 February 2010;

(5) Indian Remote Sensing (IRS) Resourcesat-1 Linear Imaging Self-Scanning Sensor (LISS) III image (path 108, row 56) DoA: 11 April 2014.

The details of the spectral and spatial resolutions of the satellite imagery used are given in the Appendix A. For all images exclusively, optical bands with $30 \mathrm{~m} \times 30 \mathrm{~m}$ spatial resolution were considered to analyze land use and land cover. In a first step, standard images were geometrically and radiometrically corrected, thereupon images were co-registered to match the overlay with sub-pixel accuracy (RMS errors $\approx 0.21$ ). For resampling, nearest-neighborhood technique was performed for the classification to retain the original pixel values.

\subsection{Methods}

In a first step, geometrically and radiometrically corrected standard images were obtained; thereupon images were co-registered to match the overlay with sub-pixel accuracy (RMS errors $\approx$ 0.21). As imagers were taken from 4 different sensors (as well as satellites), the resampling technique was performed to encounter the differences in spatial resolutions of the images used. Resampling to change the pixel size can change the neighboring pixel values; images were kept to their original pixel size despite varying accuracy levels of classification with different spatial resolution. Hence, for resampling, the nearest-neighborhood technique was performed for the classification to retain the original pixel values. A vector map of the KMC area was used for clipping and subsetting the imagery. The classification was performed on the clipped part of each imagery.

The supervised classification was employed to detect the changes in Land Use-Land Cover (LULC) within the Kolkata Municipal Corporation area (KMC) from 1980 until 2014. Classification of land use and land cover was performed on co-registered images using a non-parametrical feature-space classifier using ERDAS Imagine software (v. 2015). Three broad classes representing urban areas (associating all the urban settlements and impervious surfaces including roads and bare ground), vegetated areas (including the road side trees and open fields with grasses) and surface waterbodies (excluding the river Bhagirathi Hooghly in the west) were mapped. The application of the feature-space classifier allowed extracting broadly classified classes with a non-normal distribution [28].

For the assessment of the accuracy level of the classification procedure topographical maps (scale 1:50,000 surveyed in 1975-1976 by the Survey of India) for checking the accuracy for the image of 1980, LULC maps of 1990 \& 2000 (scale of 1:50,000; published by National Atlas and Thematic Mapping Organization, India) for the image of 1990 \& 2000, complemented by ground-truth data obtained from field surveys (using a GPS device with $1 \mathrm{~m}$ accuracy) between 2008-2016 and the analysis of secondary data (maps and other government reports) collected from the KMC within 2008-2016 were then compared with the classified satellite imagery of $2010 \& 2014$. The overall accuracy obtained is $71 \%$ (for 1980), $83 \%$ (for 1990), $81 \%$ (for 2000 ), $85 \%$ (2010), and $88.89 \%$ (for 2014). The review of literature [29-34] suggests for the acceptance of the achieved accuracies. However, these accuracies can be further improved with mixed pixel classification techniques [35]. Finally, data generated from the classified imagery were integrated into spreadsheets to calculate the changes in each class for the duration from 1980 to 2014. The areas of each class were calculated by clipping the classified imagery for each class and then multiplying the number of pixels in each image by pixel size. 


\section{Land Use-Land Cover Change in Kolkata Municipal Corporation Area Since 1980}

The supervised classification was applied to detect the changes in Land Use-Land Cover (LULC) within the Kolkata Municipal corporation area (KMC) since 1980 until 2014. It reveals the spatial patterns of the city showing the changes of the three major land use classes (1) urban settlements including all the sealed areas such as roads, (2) vegetation patches including roadside tress and green fields and (3) wetlands including all the ponds, lakes, and canals. Presentation of results follows at first an overviewing analysis for the Kolkata Municipal Corporation area (KMC) and then continues with a borough-wise analysis for the Kolkata Municipal Corporation area (KMC) to get detailed information.

\subsection{Overviewing Analysis for the Kolkata Municipal Corporation Area (KMC)}

For the Kolkata Municipal Corporation area (KMC) the three major land use classes (1) urban settlements, (2) vegetation patches, and (3) wetlands were mapped in five time slices covering the period from 1980-2014. During this time the spatial patterns of these major land use classes show distinct changes: In 1980 the urban settlements covered 49\% of the total KMC area while in 2014 it almost captured the whole KMC area covering $79 \%\left(161.91 \mathrm{Km}^{2}\right)$ of the total area (Figure 4). The urban settlements area under the KMC only slightly increased (2\%) between 1980 and 1990, transforming from $100.17 \mathrm{Km}^{2}$ to $103.89 \mathrm{Km}^{2}$. Between 1990 and 2000 the urban settlements area increased abruptly, covering $71 \%\left(145.34 \mathrm{Km}^{2}\right)$ in 2000 followed by an additional increase of $7 \%$ until 2010 (78\% or 162.08 $\mathrm{Km}^{2}$ of the total area of KMC; Figure 4). Within the whole study period (1980-2014) the space occupied by the wetlands decreased from $47.15 \mathrm{Km}^{2}$ to $8.70 \mathrm{Km}^{2}$ and that covered by vegetation patches from 58.60 $\mathrm{Km}^{2}$ to $35.31 \mathrm{Km}^{2}$ (Figure 5).

Areas of vegetation patches comprising predominantly big trees in 1980 almost covered an area of $29 \%\left(58.60 \mathrm{Km}^{2}\right)$ of the total KMC area and even expanded to $39 \%\left(81.12 \mathrm{Km}^{2}\right)$ until 1990. Since then, the area covered by vegetation patches continuously shrank, covering $21 \%$ of the total KMC area in 2000 and ultimately, 17\% in 2014 (Figure 5). Between 2010 and 2014 the area covered by vegetation patches increased slightly in the eastern part of Kolkata and in some scattered parts of southern Kolkata in comparison to the other parts of the study area. Nevertheless, at the same time the areas covered by wetlands reduced from $47.15 \mathrm{Km}^{2}$ to $20.90 \mathrm{Km}^{2}$ (Figure 6). This indicates that wetlands are not necessarily transformed directly to urbanized areas but were desiccated and overgrown by vegetation. The areas covered by wetlands decreased to more than half within the whole KMC area between 1980 and 1990 (23\% in 1980 and 10\% in 1990) (Figure 6). In the following decades the areas covered by vegetation patches as well as those covered by wetlands constantly declined. In 2014, the percentage of areas covered by wetlands accounted only $4 \%\left(8.7 \mathrm{Km}^{2}\right)$ of the total KMC area which, however, was $1 \%$ more than in $2010\left(7.42 \mathrm{Km}^{2}\right)$ (Figure 6). 

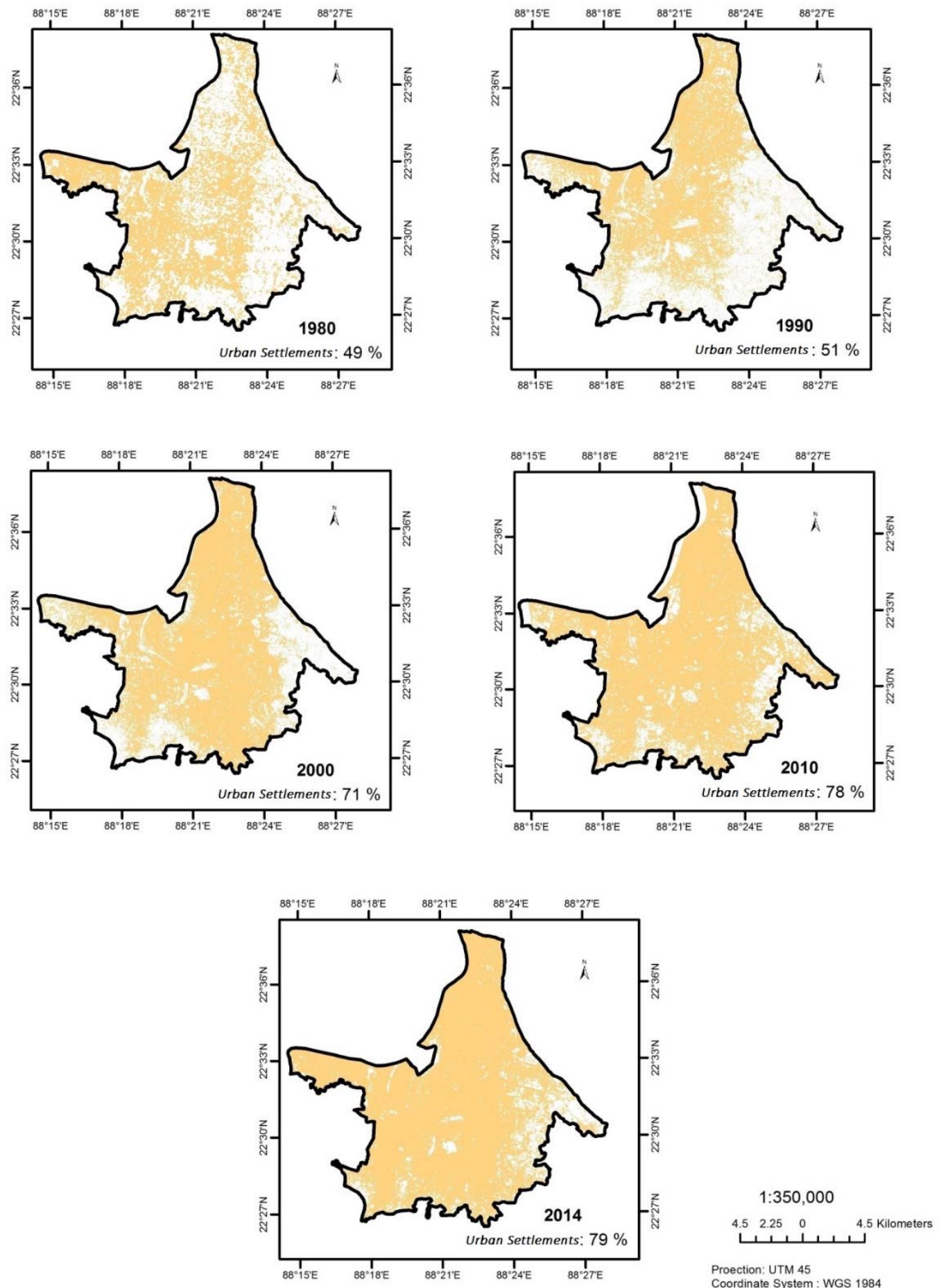

Figure 4. Distribution of urban settlements (brown patches) within Kolkata Municipal Corporation area (KMC) in time slices from 1980 to 2014 (decade-wise) (Data base courtesy: Satellite Image interpretation from Landsat (USGS) and LISS III series (ISRO, India) and the Govt. of West Bengal, India). 

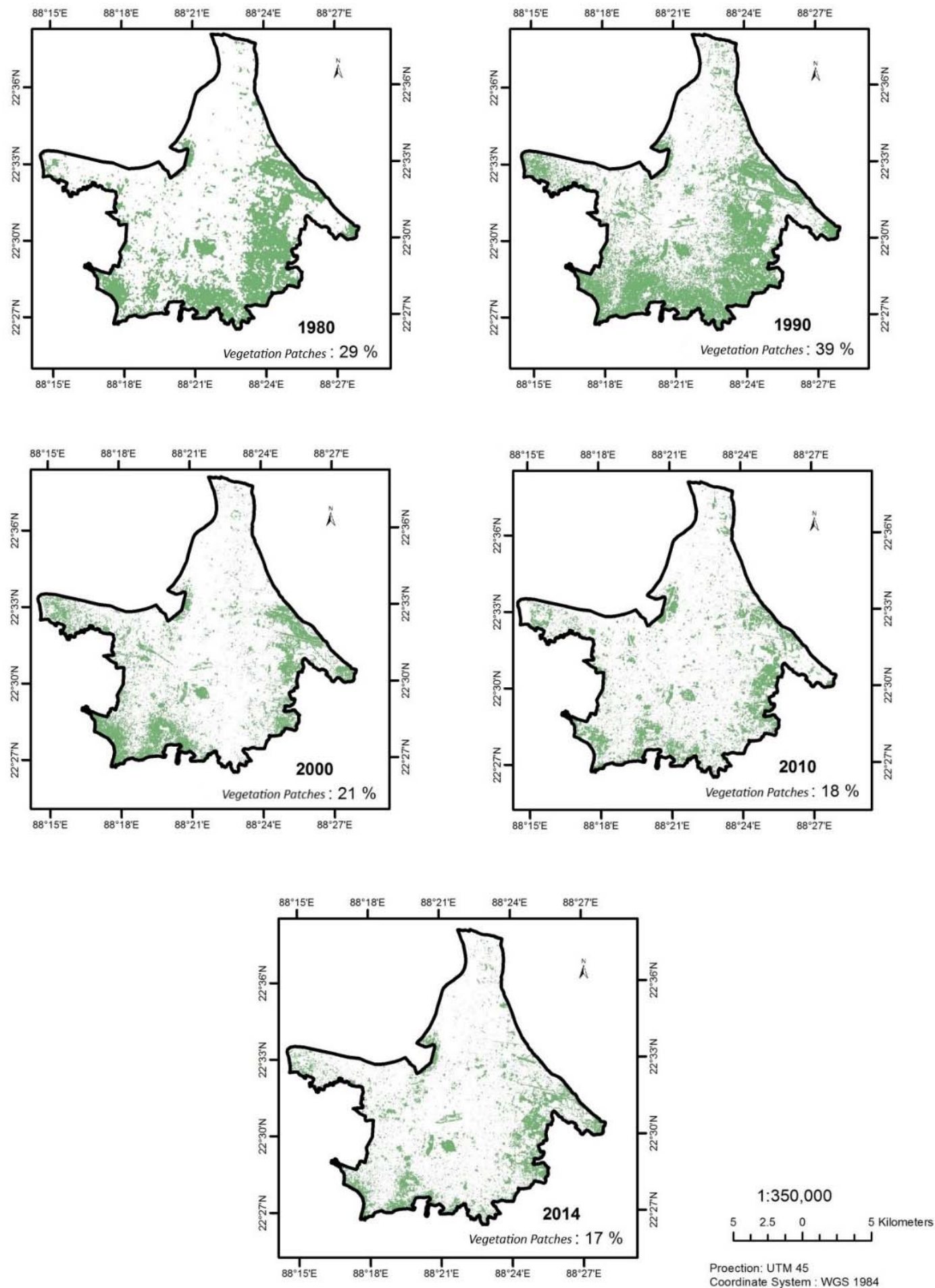

Figure 5. Distribution of vegetation patches (green patches) within Kolkata Municipal Corporation area (KMC) in time slices from 1980 to 2014 (decade-wise) (Data base courtesy: Satellite Image interpretation from Landsat (USGS) and LISS III series (ISRO, India) and the Govt. of West Bengal, India). 

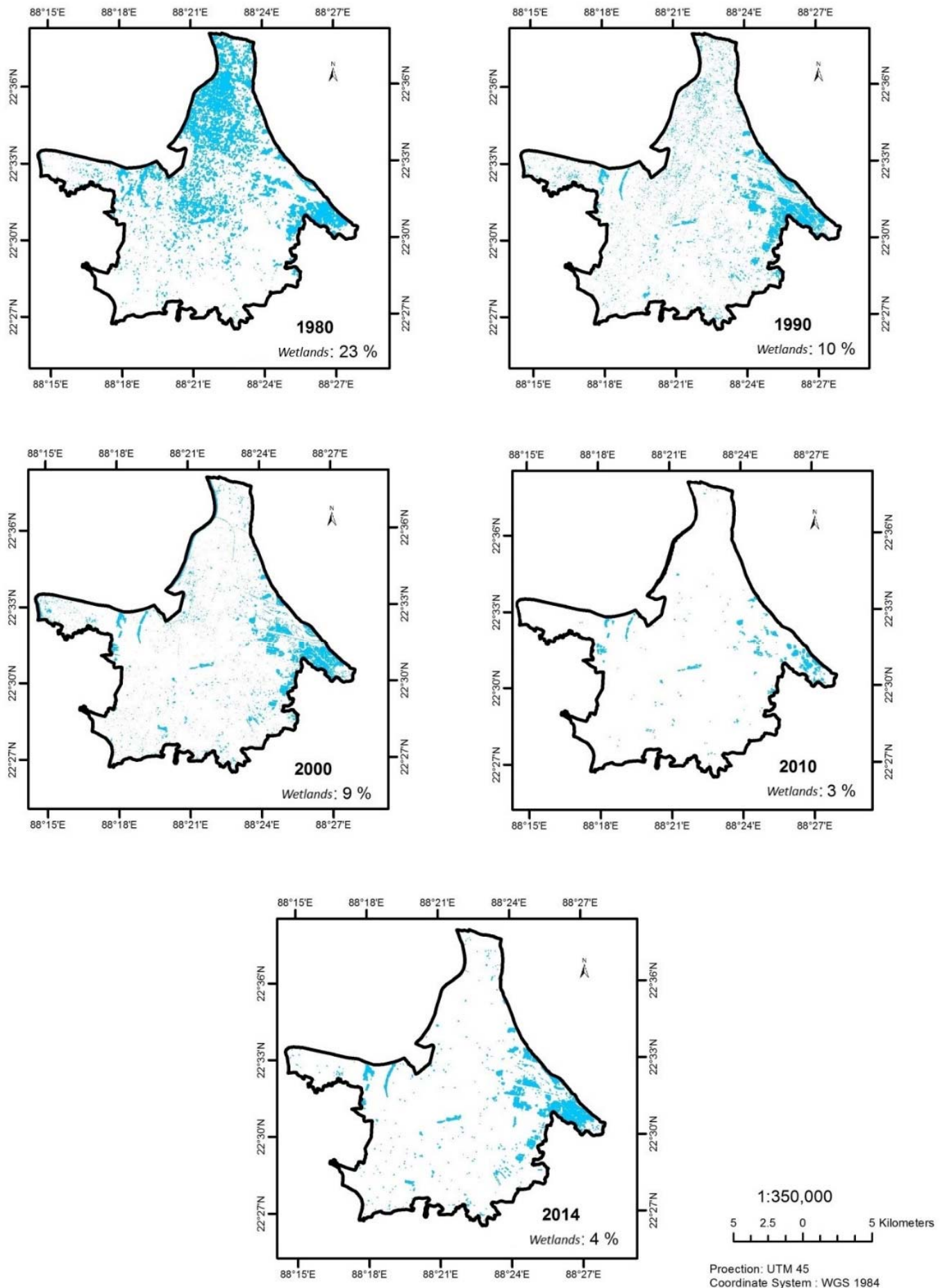

Figure 6. Distribution of wetlands (blue patches) within Kolkata Municipal Corporation area (KMC) area from 1980 to 2014 (decade-wise) (Data base courtesy: Satellite Image interpretation from Landsat (USGS) and LISS III series (ISRO, India) and the Govt. of West Bengal, India).

\subsection{Borough-Wise Analysis for the Kolkata Municipal Corporation Area (KMC)}

For spatially more detailed analyses of land use-land cover the wards were clustered into boroughs. The results show borough-wise the amount of increase and decrease of spatial distribution of the three broad land use-land cover classes throughout the study period in percentage (Figure 7) and in $\mathrm{km}^{2}$ (Figure 8). The distribution of impervious urban area covered in $201475 \%$ or more of the KMC 
(Figure 7). The variations in the spread of the three major land cover classes itemized by boroughs clearly indicates that the spread of urban settlements took place by replacing areas allocated to vegetation patches or wetlands. The results reveal that boroughs II, IV, V, and VI, which are mainly concentrated in the north and center of the KMC, lost major areas of wetlands within 1980 to 2014.

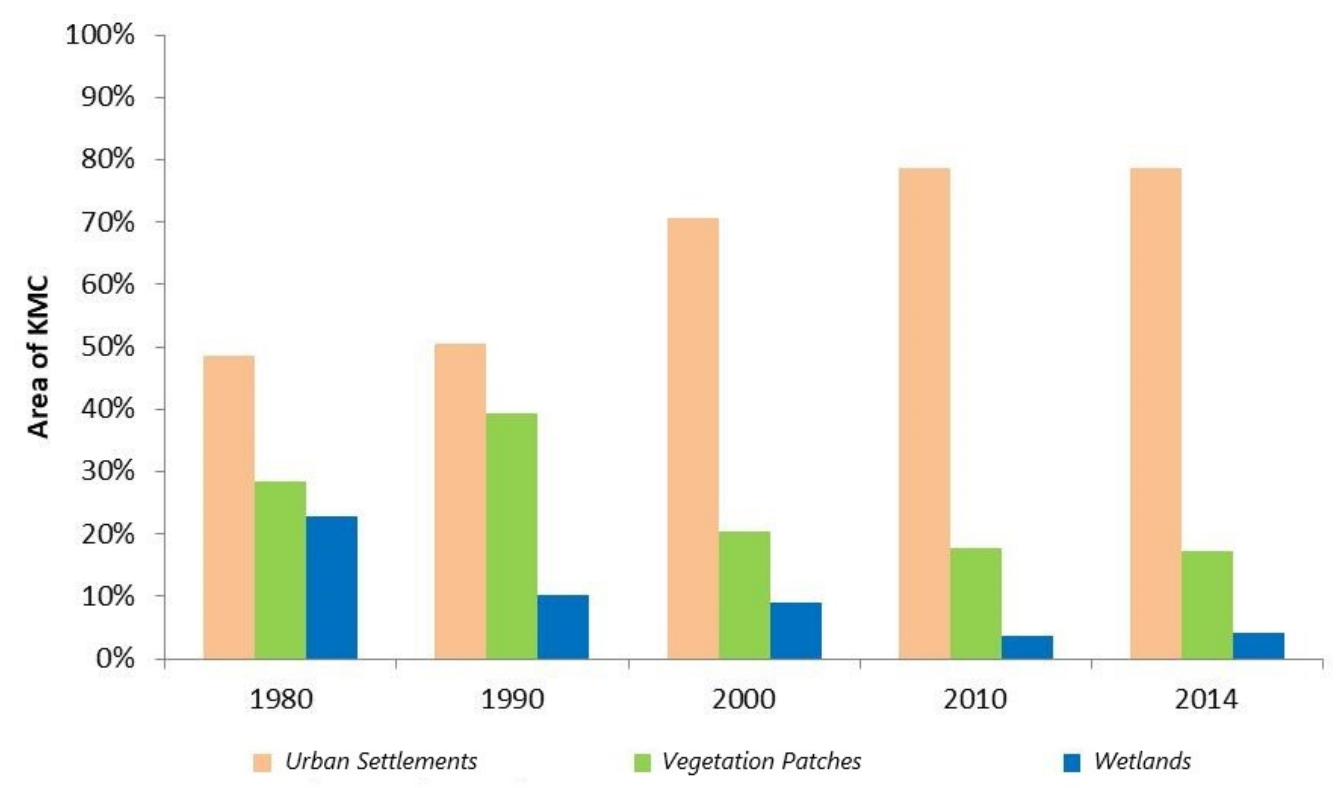

Figure 7. Relative distribution of major land use-land cover classes in Kolkata Municipal Corporation area (KMC) showed decade-wise since 1980. Major land use-land cover classes are differentiated into urban settlements, vegetation patches, and wetlands; also compare Figures 4-6. (Data base courtesy: Satellite Image interpretation from Landsat (USGS) and LISS III series (ISRO, India) and the Govt. of West Bengal, India).

Borough-wise results for the first decade studied (1980-1990) (Figure 8) depict that all the boroughs except boroughs no. VII, IX, and XII lost almost the entire wetlands areas by 2014 (Figure 8). The most severe loss in wetlands is observed for borough II, where the area declined from $84 \%$ to $14 \%$. In contrast, within borough II, urban settlements increased from 16\% to 84\% between 1980 and 2014 (Figure 8). In the decade of 1990 to 2000, the distribution of vegetation patches and the areas covered by wetlands declined in almost all the boroughs of KMC, but the major declines were evident in boroughs in the central and northern part of the KMC (I, III, VII, VIII, XI and XIII) for vegetation patches and borough II in the north of the KMC for the spread of wetlands. Within the decade from 2000 to 2010 urban settlements continued spreading within the KMC covering an area of $162.08 \mathrm{~km}^{2}$ in 2010 (2000: $145.33 \mathrm{~km}^{2}$ ). Concurrently, areas covered by vegetation patches continuously declined from $41.96 \mathrm{Km}^{2}$ (2000) to $36.43 \mathrm{Km}^{2}$ (2010). Even more pronounced the spread of wetlands declined from $18.62 \mathrm{Km}^{2}$ (2000) and $7.42 \mathrm{Km}^{2}$ (2010). These trends stopped or even reversed between 2000 and 2014 when urban settlements covered 161.91 $\mathrm{Km}^{2}$ (+8\% compared to 2000$)$, areas under vegetation patches covering $35.31 \mathrm{Km}^{2}$ ( $-4 \%$ compared to $2000)$ and wetlands covered $8.70 \mathrm{Km}^{2}$ (-5\% compared to 2000) of the KMC in 2014. These changes became particularly apparent in the southern part of the KMC (Figures 5-7), which gets especially apparent by the borough wise break down of the land use-land cover change (Figures 8 and 9). 

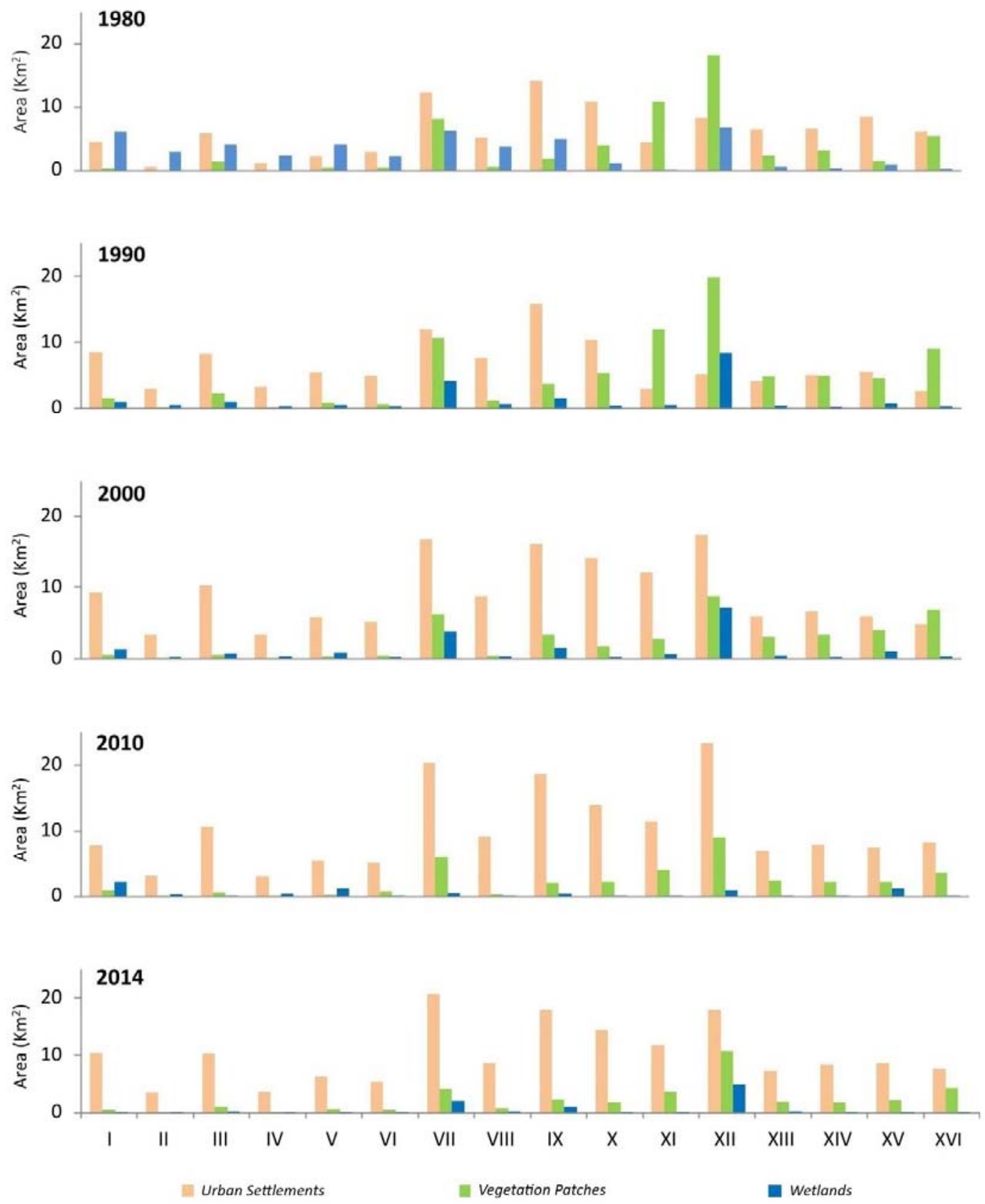

Boroughs

Figure 8. Borough-wise decadal distribution of the major land use-land cover classes $\left(\mathrm{km}^{2}\right)$ in Kolkata Municipal Corporation area (KMC) decade-wise since 1980 differentiated into (a) urban settlements (built-up and sealed areas), (b) vegetation patches and (c) wetlands. (Data base courtesy: Satellite Image interpretation from Landsat (USGS) and LISS III series (ISRO, India) and the Govt. of West Bengal, India). 

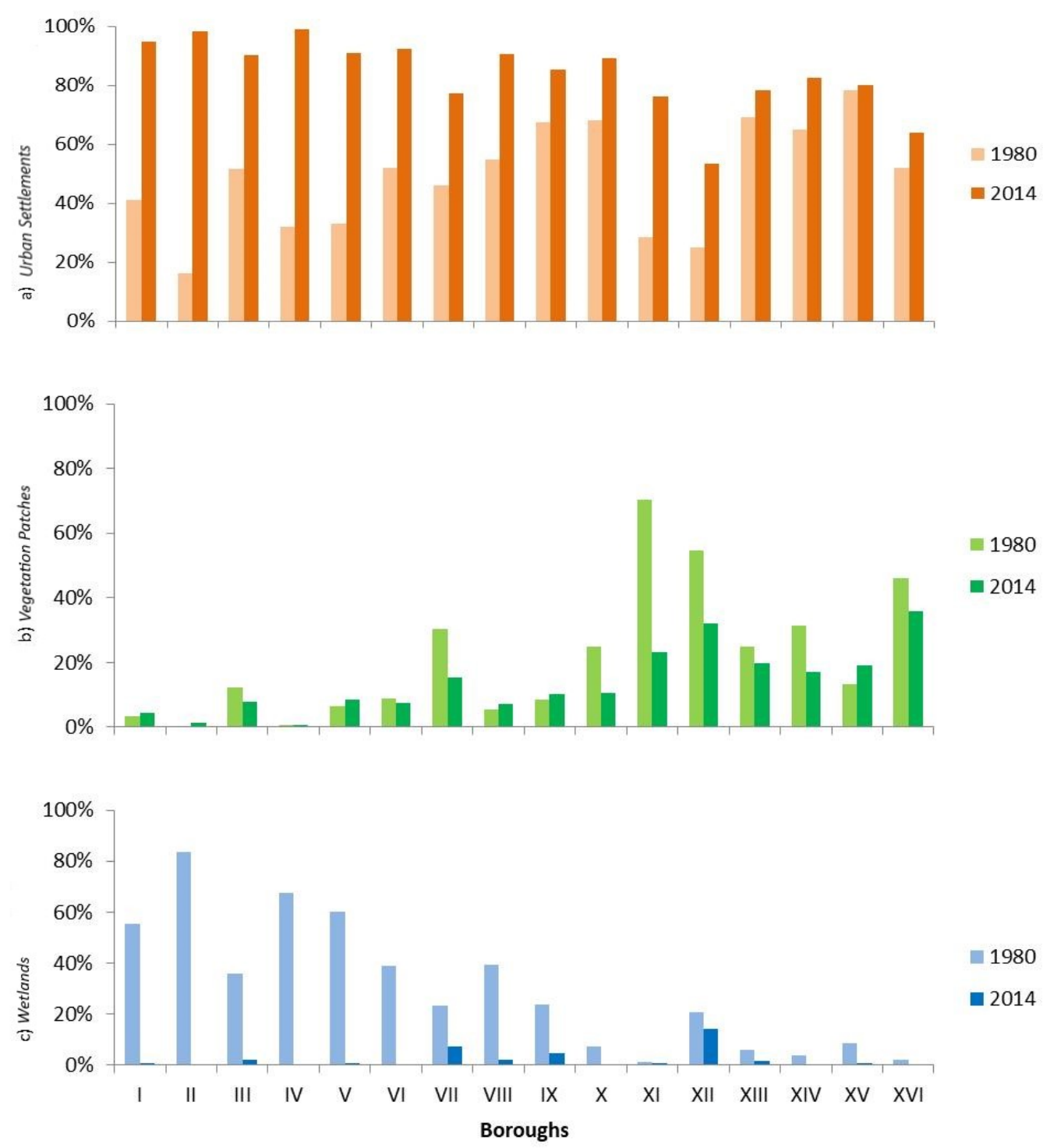

Figure 9. Borough wise differentiated relative distribution of major land use-land cover classes in Kolkata Municipal Corporation area (KMC) in 1980 and 2014. Major land use-land cover classes are shown differentiated by in (a) urban settlements, (b) vegetation patches, and (c) wetlands. (Data base courtesy: Satellite Image interpretation from Landsat (USGS) and LISS III series (ISRO, India) and the Govt. of West Bengal, India).

The relative change of the distribution of each major land use-land cover class was calculated dividing the difference in area coverage between 1980 and 2014 by the area covered by the respected land use-land cover class in 2014. The positive results of a class signify the increase whereas the negative results indicate the decrease in areas between 1980 and 2014 (Figure 10). Areas covered by wetlands show the highest relative decrease in distribution; in boroughs I to VI the areas under the coverage of any lake, ponds, or other surface waterbodies in 1980 changed until 2014 either into urban settlements or vegetation patches. The distribution of vegetation patches declined in the boroughs X, XI, and XII between 1980 and 2014, being transformed into urban settlements. The change for the vegetation patches were major in the boroughs of II, VI, and V. Simultaneously, a continuous and stable process of urbanization occurred in boroughs X-XVI. Nevertheless, the areas covered by wetlands were mainly changed in the boroughs I-VIII (Figure 10). 


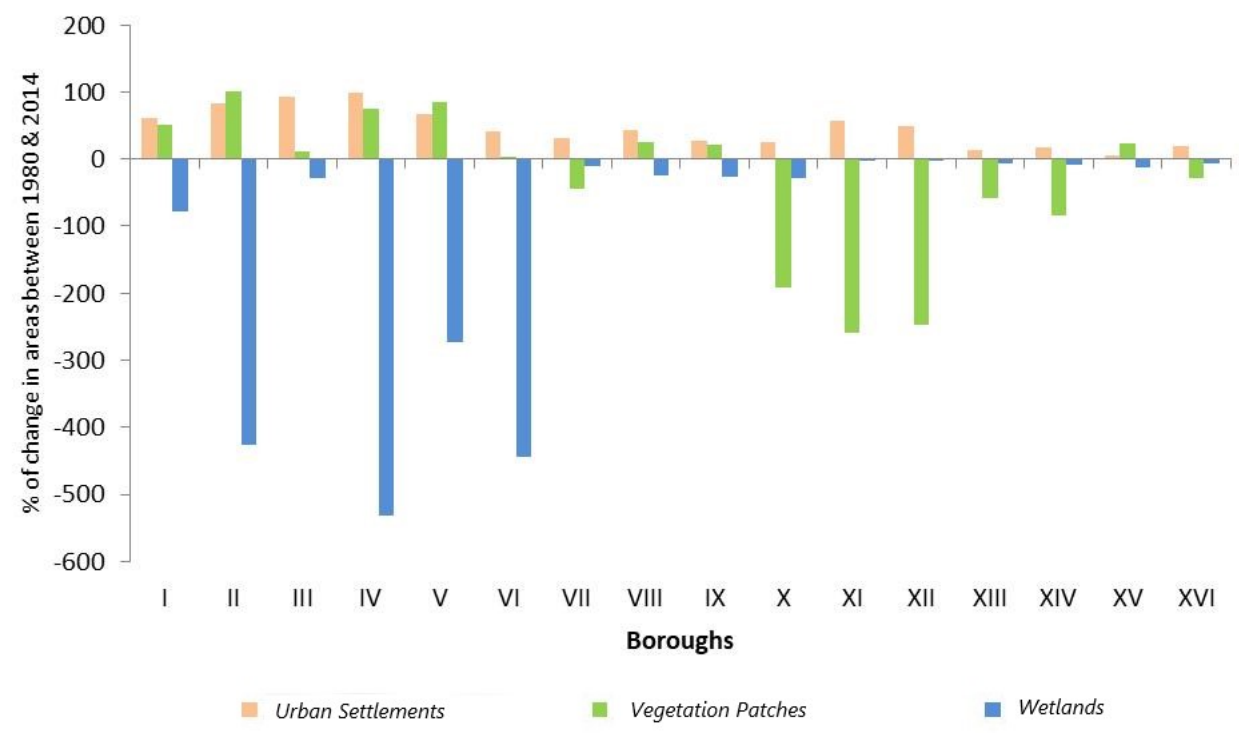

Figure 10. Borough-wise change (\%) of urban settlements, vegetation patches, and wetlands in Kolkata Municipal Corporation area (KMC) from 1980 to 2014. (Data base courtesy: Satellite Image interpretation from Landsat (USGS) and LISS III series (ISRO, India) and the Govt. of West Bengal, India).

\section{Water Security in Kolkata Municipal Corporation Area}

Changes in land use-land cover patterns increase pressures on water resources, which ultimately affects the linkage between land tenure and water security [36]. This section seeks to complement the observations on land use-land cover change by a literature review to contribute to developing a shared understanding of some of the core concepts related to water security in Kolkata city. Rapid changes in land use-land cover patterns and simultaneous insufficient water management practices in the entire KMC area caused poor water quality [37]. Water security entails ensuring every citizen with the amount of quality water they need to safely live their everyday life [36]. In an urbanized area, amongst other aspects, unrestricted population growth [38,39], poor governance [40-42] and mismanagement of the water supply system [43] as well as social inequity [44-46] can result in water insecurity.

The nature of urbanization processes has undergone a paradigm shift since the neo-liberal economic reforms of 1991, which ultimately leads the process of the acquisition of land and water, creating a potential insecurity for the urban water system in the KMC area [8,36]. In addition, parallel physical processes like climate change accelerate the insecurity of water $[47,48]$. The following section picks three major aspects of urban water security: water demand and supply, water accessibility, and water related disasters, which include risks and environmental health.

\subsection{Water Demand and Supply}

Time series analysis of land use-land cover change in Kolkata Municipal Corporation (KMC) area shows that Kolkata city has been transformed during the past four decades into almost a completely urbanized area. Population growth and resulting population density (Table 3) are the most important drivers that act as Catalysts for urbanization. Founded by the British East India Company in the early 17th century, Kolkata was the first major Asian city which evolved as a provincial city and eventually became the headquarters of the British India government [49]. The amount of its population, Kolkata's importance in trade and commerce, the varieties of employment that it offers, and the diverse nature of its inhabitants make it a cosmopolitan city in character [50]. 
Table 3. Population data of Kolkata Municipal Corporation area (KMC) from 1971 to 2011 according to the Census of India [23].

\begin{tabular}{ccccc}
\hline \multirow{2}{*}{ Years } & \multicolumn{3}{c}{ Population } & \multirow{2}{*}{ Growth Rate (\%) } \\
\cline { 2 - 4 } & Total & Male & Female & \\
\hline 1961 & $2,927,298$ & $1,815,791$ & $1,111,498$ & +8.48 \\
1971 & $3,148,746$ & $1,924,505$ & $1,224,241$ & +7.57 \\
1981 & $3,305,006$ & $1,930,320$ & $1,374,686$ & +4.96 \\
1991 & $4,399,819$ & - & - & +33.12 \\
2001 & $4,572,8976$ & $2,500,040$ & $2,072,836$ & +3.93 \\
2011 & $4,486,679$ & $2,362,662$ & $2,124,017$ & -1.88 \\
\hline
\end{tabular}

At the beginning of the 20th century, Kolkata was the first city in India with a population of more than one million inhabitants. According to the 1901 census KMC area's population totaled 933,754 , while according to the 1951 census 2,698,494 inhabitants were counted and increased to 4,572,876 inhabitants in 2001 [23]. Corresponding to the last Census report of India (2011), the decadal growth rate of population in the Kolkata Urban Area (including KMC) amounted 6.87\% between 2001 and 2011, which was far below the standard growth rate of India or West Bengal state [51]. This declining population growth rate in the KMC area has been covered up by the continually increasing population growth rate of greater Kolkata agglomeration areas, especially in the peri-urban zones along the banks of river Hooghly. As per the 2011 census, the KMC area had a population of 4,496,694, of which $52.41 \%$ ( $54.67 \%$ in 2001 ) were male and $47.58 \%$ ( $45.33 \%$ in 2001 ) were female. The population density of KMC area averaged 22,000 inhabitants per $\mathrm{km}^{2}$ (24,718 inhabitants per $\mathrm{km}^{2}$ in 2001) [23]. The population growth and rigorous sprawling impacts on the changing nature of the land use-land cover within $\mathrm{KMC}$ area cause an increasing demand of water in the city and impose stress on the local ground water regime [20]. This results in increased pressure on the existing demand-supply system and basic infrastructural functionality according to recent reports on water demand [20,52].

Rapid and uncontrolled growth of urban areas is the result of, firstly, the natural increase in population, and secondly, migration into urban areas [53]. In total, migration significantly contributes to the urban growth of Kolkata [53,54]. According to the 2007-2008 census data, the migrant population in Kolkata city amounted for $30.9 \%$ of the total KMC population; work participation rate of migrants within KMC (44.5\%) is much higher than West Bengal (34.7\%) and in India (37.3\%) [52]. Although insignificant, comparing to the migration of people within India, international migration (mainly, refugees and undocumented migrants during and after the Bangladesh Liberation War of 1971) also must be considered as a growth factor. By the beginning of the 20th century, the urbanization in Kolkata took place majorly along the eastern bank of the river Hooghly (currently areas under KMC boroughs I-VII). Since the 1980s most of the surface waterbodies in the peri-urban areas of KMC were impoldered and sealed [20]. Table 3 reflects the total population and its decadal growth rates in the KMC area since 1961 until 2011: The population growth rate in 1961 was higher than in 1971 and 1981; nevertheless, the growth rate increased and peaked in 1991. An important factor triggering rapid urbanization is economic growth and its related development of infrastructural facilities $[55,56]$, frequently forcing uncontrolled urban sprawl $[53,57]$. In general, the rapid growth of cities stresses their capacity to provide technical infrastructure and services such as energy, education, health care, transportation, and sanitation. Since governments have less revenue to provide the basic maintenance and provision of services, massive urban sprawl occurs, locally affecting urban ecosystem [53]. In many developing countries rapid urbanization and low levels of technology are expected to affect ecosystem services and to put more pressure on the urban community to cope with these changes [58]. Studies like [3] can be combined with the frequent LULC changes to predict the futuristic pressure on the urbanization in accordance with water security.

KMC's water supply system is based on both, surface and subsurface waters [59]. Bhagirathi-Hooghly, a major distributary of the Ganga about $500 \mathrm{~km}$ in length, is the main water 
source for the entire city's water supply system. In 1997, the average water supply for KMC's urban population lasted less than four hours a day [60]. In 2014, in India (data from 28 cities) daily water supply was $3.3 \mathrm{~h}$ on average while the hours of supply varied from $1 \mathrm{~h}$ per 3 days to $18 \mathrm{~h}$ per day [61]. In contrast, in KMC the daily water supply was still $4 \mathrm{~h}$ on average, while serving $81 \%$ of population and providing an average of $123 \mathrm{~L}$ per capita per day [27]. It exceeds the national average of $71.2 \%$ in terms of the number of the people served (Table 4) [27,62].

Leakage from piped water supply systems, mainly originating from rusted iron pipes frequently causes interruption of the water supply [25]. Leaky water pipes expose the drinking water to contamination and, thus, affect the public health [63]. Leakage and cracks in the piped water system also might cause fecal contamination of drinking water, which turns the whole system into insecurity [50]. However, according to the Central Pollution Control Board of India (CPCB), Indian cities should focus on the required availability and quality of the supplied drinking water (64). In 2006 and 2011, all over India the non-revenue water due to leakages, unauthorized connections, billing, and collection inefficiencies, etc., was estimated to be $40-70 \%$ of the water distributed [64-66]. For Kolkata the economic effects of water leakage can be sketched as follows: water is supplied through a distribution network of $5500 \mathrm{~km}$ of underground water pipes, supported by 13 pumping stations in the four zonal mains [12]. 30-35\% of the pumped water is lost during transmission either through leaks or theft. The resulting costs of water loss are estimated to about 2.7 million rupees annually (treated at 4.50 rupees per $1000 \mathrm{~L}$ ) [67].

Table 4. Comparison between National and Municipal Urban Service Delivery Status in Kolkata Municipal Corporation [23,62].

\begin{tabular}{ccccccc}
\hline & \multicolumn{5}{c}{ Water Supply } & Sewerage \\
\cline { 2 - 7 } & $\begin{array}{c}\text { Coverage } \\
(\%)\end{array}$ & $\begin{array}{c}\text { Per Capital } \\
\text { Amount (IPCD) }\end{array}$ & $\begin{array}{c}\text { Hours } \\
\text { (Hours/Day) }\end{array}$ & $\begin{array}{c}\text { Non-Revenue } \\
\text { Water }\end{array}$ & $\begin{array}{c}\text { Metered } \\
\text { Connections (\%) }\end{array}$ & $\begin{array}{c}\text { Coverage } \\
\text { (\%) }\end{array}$ \\
\hline $\begin{array}{c}\text { National } \\
\text { Average }\end{array}$ & 81 & 123 & 4 & - & 25 & 28 \\
KMC & 92 & 134 & 8 & 93 & 0.1 & 43 \\
\hline
\end{tabular}

Groundwater, the second major source of fresh water in the KMA, gets extracted for domestic and agricultural use in large quantities in areas distant from the river [26]. Due to the hydrogeologic situation of Kolkata city, groundwater contamination by infiltration of polluted floodwater is constricted [20]. Nevertheless, Kolkata and the Ganga-Brahmaputra delta lie in a geological zone with naturally occurring arsenic in deeper strata. In consequence, arsenic concentrations higher than the WHO's recommended maximum concentrations of $10 \mu \mathrm{g} \cdot \mathrm{L}^{-1}$ were detected in groundwater from 65 of 100 sampled wards in Kolkata monitored over a twenty-year study period [68]. The natural occurrence of arsenic in the aquifer is exacerbated by the over-extraction of groundwater [69]. A most recent study shows that the groundwater extraction in the KMC area was about $32 \times 10^{4} \mathrm{~m}^{3}$ per day and significantly exceeded groundwater recharge [70]. Over-extraction of the groundwater and reduced rate of aquifer recharge also cause ground subsidence [71].

\subsection{Water Accessibility}

Changes in land use-land cover influence the interaction of structural and behavioral factors associated with technological and environmental capacity, demand-supply and social relations. As a result, the increased physical water demand of the growing population affects the accessibility of water for the citizens [72]. In case of urban India, nearly $70 \%$ of the households have access to tap water, out of which $62 \%$ have access to treated tap water [25]. Correspondingly, less than $30 \%$ of Indian urban households depend on other sources of water than tap water [23-25]. All over India less than $50 \%$ of the urban population has access to piped water within their premises [23]. In 2007, in the KMC area around $74 \%$ of the population were served with water by house connections (and public taps in case of slum areas) and provided continuous and uninterrupted water supply of $8.3 \mathrm{~h}$ daily [60]; the rest of 
the households were accessing groundwater through private pumps or wells [60]. In the census data from 2011 [23], the percentage of households having access to piped water within the KMA increased to $79 \%[17,66]$.

Between 2006 and 2011 revenues from user charges covered c. 30-40\% of the operation and maintenance costs of the water supply and sanitation infrastructure within the KMC area $[65,66]$. The KMC does not levy tax on drinking water for the citizens [73]. Most urban water supply operations survive on large operating subsidies and capital grants [66]. The policy of not pricing water for domestic use has received the authority's criticism as it sends the wrong signals to consumers, thus promoting wastage [60,74]. The consequence of underpricing, coming along with KMC's overstaffing and large amount of unaccounted water is that KMC can hardly cover maintenance costs or provide capital through tariff revenues for infrastructure improvement [26,74]. KMC's recovery of operational costs with an average of $15 \%$ is one of the lowest among Indian cities [74]. According to Majumdar \& Gupta (2009), the issue of water conservation within the KMC area is completely neglected, which over time has also required a mounting of government subsidies on water [75]. An analysis of the decade (from 1992 to 2002) reports that the expenditure for water supply and sewerage increased five times, whereas revenues only doubled [75]. Additionally, there has been a sharp decline in the groundwater level, especially in central to south Kolkata as well as along the Eastern Metropolitan Bypass in the east of KMC area (Rajpur-Sonarpur areas). In both areas settling-up intensified in recent years with the newly settled areas being only barely tapped [13]. In consequence, the wealthy residents settling in these newly constructed multi-story apartment blocks pump their own water as they do not trust on the quality of the water supplied by civic bodies. Groundwater pumping within KMA is increased wherever the access to surface water is limited [13].

Slums result from uncontrolled and invariable urban sprawl in and around Kolkata city since the Colonial era. Kolkata's slums are characterized by high socio-economic and ethnic disparities and accommodate approximately one third of Kolkata's population, occupying about half of the Kolkata metropolitan area (KMA) $[13,23,24]$. Slums and squatter settlements are in general physically distinct, with tile roofed kutcha huts, often made of brick, mud, and wattle, and are poorly serviced in terms of water, sanitation, sewerage, drainage, and waste disposal [53]. Accessibility to the public water supply is limited and is mostly only available at some few stand posts [13]; during the summer days the supply shortage generally increases, and water quality degrades [76]. The water supply provision of KMC does not sufficiently cover the water demand of these slum areas with $90 \mathrm{~L}$ per capita per day (lpd) while the estimated water demand of KMC's inhabitants amounts to $180 \mathrm{lpd}$ [77].

Poor and inadequate living conditions and municipal services increase the chances of lethal health and sanitation issues [78]. These problems are especially critical in slums and squatters in fringe areas [49]. Peri-urban fringe areas (e.g., newly added wards, such as 101, 141-146) are lacking access to piped water supply from the municipality. The residents must either use the groundwater through handheld tube wells or get access from KMC supports such as water delivery by water trucks a few times a week. The increasing numbers of slum dwellers have been the key concerns for urban planning in respect to accessibility of safe drinking water and availability of adequate sanitation facilities [79].

\subsection{Water Related Disasters}

In Kolkata seasonal flooding and its impact on the environment affects human health and is a significant challenge. Established in the Ganga delta frequent flooding is a natural phenomenon. Urban spread and unplanned occupation of the natural drainage system is a major source for the exposure of urbanized areas to flooding. $17.3 \%$ of Kolkata's population live in areas of high flood risk (especially in ward numbers $14,57,58,63,66,67,74,80,108,111-115$, and 122-126; Table 1) [80]. These high-risk areas are located along canals and wetland areas that originally served as by-pass or retention areas during flooding while today most of the canals are superstructed [80]. The land use-land cover changes observed in the class of urban settlements clearly show that urbanization processes affected the distribution surface waterbodies during the observation period (1980-2014). It resulted in the drainage 
of wetlands and its replacement by either compact surfaces or barren land for further development. Another reason for the shrinkage of surface waterbodies was the vanishing of the trees in the city and the resultant increased surface runoff [80]. Consequently, the groundwater table lowered [81-84]. With the increasing surface runoff and due to the poor sanitation conditions in these areas contamination of surface waterbodies by dissolved and solid matters increased. To improve water quality, 25 sewage treatment plants (STPS) have been installed in West Bengal under phase II of the Ganga Action Plan between 1993 and 1996, but the capacity available is still not sufficient [85]. There are two sewage treatment plants (Bangur and Garden Reach STPs) installed outside the KMC area receiving waste water from the KMC area; both were underutilized due to a lack of household connections in their catchments, as until 2006 only $17 \%$ of the population in these areas had sewer connections $[85,86]$. Due to the insufficiency of these measures dissolved oxygen levels, measured in July 2007 by the National River Conservation Directorate and WBPCB, pointed out unsuitable bathing conditions at all monitoring stations in Kolkata when the value of dissolved oxygen levels reached less than $4 \mathrm{mg}$ $\mathrm{O}_{2} \mathrm{~L}^{-1}$ [85]. Beyond, the total coliform count has been rising: while the average levels of coliforms in 2001-2002 were mostly within levels deemed to be suitable for bathing (max. 500 most probable numbers $\times 100 \mathrm{~mL}^{-1}$ ), the 2005-2006 average increased to 423,125 most probable numbers $\times 100$ $\mathrm{mL}^{-1}$ at the Howrah Monitoring Station [85]. During severe flooding, such as in September 1999, the slum areas suffered from a paucity of power supply, acute shortages of safe drinking water, out breaks of water borne diseases such as Gastro-enteritis, Typhoid, Entamoebiasis, Hepatitis etc., and a long period of water logging [81].

Palit et al. (2012) conducted a study on the potential of different water sources, both for drinking and domestic purposes, for diarrheal disease transmission in Kolkata's urban slums [87]. The results show a significantly higher prevalence of fecal coliforms (58\%) in stored water for washing than the stored water for drinking (28\%) and tap/tube well water ( $8 \%$ ) collected [87]. Samples containing stored water for washing also had the highest non-permissible range of physico-chemical parameters. Household water containers storing water for washing were rich in fecal coliforms and residual chlorine contents. Palit et al. (2012) found less than the satisfactory level of residual chlorine (57\%), TDS $(37 \%)$, and $\mathrm{pH}(20 \%)$ present in almost two thirds of the samples of water stored for washing [87].

The urbanization processes in the KMC area over the past four decades went along with a decline in vegetation cover and water bodies (Figures 7 and 8). The loss of green spaces coinciding with an increase of built-up and sealed areas affects surface temperatures and causes the development of urban heat islands [88]. Urban heat islands in turn have effects on rainfall patterns and intensities, threaten biodiversity, and consequently affect water security $[26,88]$. The eastward expansion of Kolkata has been accommodated at the expense of natural ecosystems, mainly the East Kolkata Wetlands. The Basic Development Plan for the city completely disregards the ecological sensitivity of the East Kolkata Wetlands and proposes to develop two major townships near them [26]. Reclamation of wetlands for other commercial usages such as garbage dumping also seems to continue unabated, according to the same WWF India report (2011) [26]. In consequence, unplanned and rough handled socio-economic activities in the Kolkata Metropolitan area stress water quality [26,88,89].

\section{Conclusions}

This review provides a qualitative snapshot on the effects of land use-land cover change and water management strategies to urban water insecurity in Kolkata Municipal Corporation (KMC) area during the last four decades. Beyond water's functions in the hydrological cycle, it has social, economic, and environmental values, and is essential for sustainable development. Unprecedented population growth, a changing climate, rapid urbanization, expansion of infrastructure, migration, land conversion, and pollution translate into changes in the water fluxes, water pathways, and water stores. Population density and per capita resource use have increased dramatically over the past four decades in KMC area; parallel, urban ecosystems have undergone significant modifications that affect the vitality, quality, and availability of the water resources in KMC. The trends observed in 
land use-land cover change in the KMC area reveal the drivers of the environmental changes which indirectly, sometimes directly, affect the urban water security of KMC. Major driver is uncontrolled urbanization. Increased water use associated with domestic and small-scale industries and real estate business is leading to changes in water supply infrastructure, high rates of groundwater use, and new water conveyance networks. Collectively these changes lead to cumulative effects on water quality and quantity of available water resources. Hence, the review envisages the relationship between urban water-based livelihood, water pollution, stakeholder interventions, and institutional responses. Selection, quantification, and integration of responsible bio-physical and socio-economic factors are needed to be studied in details in the future and transferred into the policy that combines bio-physical and social dimensions of the urban water security and governance.

Author Contributions: Conceptualization; Methodology, Software, Validation, Formal Analysis, Investigation, Resources, Data Curation, Writing-Original Draft Preparation, S.M.; Writing-Review \& Editing, S.M., W.B. and B.S.; Visualization, S.M.; Supervision, W.B. and B.S.; Project Administration, S.M., W.B. and B.S.; Funding Acquisition, S.M. and B.S.

Funding: This research was funded by the German Academic Exchange Service (DAAD: Deutscher Akademischer Austauschdienst).

Acknowledgments: We thank our colleagues from Freie Universität Berlin who provided insight and expertise that greatly assisted the research. We thank Basudeb Bhatta (Jadavpur University-Kolkata), Kalyan Rudra (WBPCB-Kolkata), Ayan Guin and Ena Sen (IESWM-Kolkata) for assistance with providing data and comments that greatly improved the research and manuscript. We would also like to show our gratitude to Pradip Sikdar (IISWBM- Kolkata) for sharing his pearls of wisdom with us during this research. We are also immensely grateful to Jan Krause (Freie University Berlin), Sukdeb Pal (NEERI-India) and Arunagshu Mukherjee (CGWB-India) for their comments on an earlier version of the manuscript.

Conflicts of Interest: The authors declare no conflict of interest.

\section{Appendix A}

Table A1. Details of the Spectral and Spatial resolutions of the Satellite Imagery used.

\begin{tabular}{|c|c|c|c|}
\hline Satellite-Sensor & Bands & Spectral Resolution $(\mu \mathrm{m})$ & Spatial Resolution (m) \\
\hline \multirow{4}{*}{ Landsat-MSS } & 1 & $0.5-0.6$ & \multirow{4}{*}{60} \\
\hline & 2 & $0.6-0.7$ & \\
\hline & 3 & $0.7-0.8$ & \\
\hline & 4 & $0.8-1.1$ & \\
\hline \multirow{6}{*}{ Landsat-TM } & 1 & $0.45-0.52$ & \multirow{6}{*}{30} \\
\hline & 2 & $0.52-0.60$ & \\
\hline & 3 & $0.63-0.69$ & \\
\hline & 4 & $0.76-0.90$ & \\
\hline & 5 & $1.55-1.75$ & \\
\hline & 7 & $2.08-2.35$ & \\
\hline \multirow{6}{*}{ Landsat-ETM+ } & 1 & $0.45-0.52$ & \multirow{6}{*}{30} \\
\hline & 2 & $0.52-0.60$ & \\
\hline & 3 & $0.63-0.69$ & \\
\hline & 4 & $0.76-0.90$ & \\
\hline & 5 & $1.55-1.75$ & \\
\hline & 7 & $2.08-2.35$ & \\
\hline \multirow{4}{*}{ Resourcesat-1 LISS-III } & 2 & $0.52-0.59$ & \multirow{4}{*}{23.5} \\
\hline & 3 & $0.62-0.68$ & \\
\hline & 4 & $0.77-0.86$ & \\
\hline & 5 & $1.55-1.70$ & \\
\hline
\end{tabular}




\section{References}

1. Mohan, M.; Pathan, S.; Narendrareddy, K.; Kandya, A.; Pandey, S. Dynamics of Urbanization and Its Impact on Land-Use/Land-Cover: A Case Study of Megacity Delhi. J. Environ. Prot. 2011, 2, 1274-1283. [CrossRef]

2. Maiti, S.; Agrawal, P.K. Environmental Degradation in the Context of Growing Urbanization: A Focus on the Metropolitan Cities of India. J. Hum. Ecol. 2005, 17, 277-287. [CrossRef]

3. Mukhopadhaya, S. Land use and land cover change modelling using CA-Markov Case study: Deforestation Analysis of Doon Valley. J. Agroecol. Nat. Resour. Manag. 2016, 3, 1-5. Available online: http:/ / www.krishisanskriti.org/vol_image/09Jun201607065902\%20\%20\%20\%20\%20\%20\%20\%20\% 20\%20Sayan\%20Mukhopadhaya\%202\%20\%20\%20\%20\%20\%20\%201-5.pdf (accessed on 3 July 2018).

4. Reveshty, M.A. The assessment and predicting of land use changes to urban area using multi-temporal satellite imagery and GIS: A case study on Zanjan, Iran (1984-2011). J. Geogr. Inform. Syst. 2011, 3, $298-305$.

5. Ramachandra, T.V.; Bharath, A.H.; Sreekantha, S. Spatial Metrics based Landscape Structure and Dynamics Assessment for an emerging Indian Megalopolis. Int. J. Adv. Res. Artif. Intell. 2012, 1, 48-57.

6. Sudhira, H.S.; Ramachandra, T.V.; Jagadish, K.S. Urban sprawl: Metrics, dynamics and modelling using GIS. Int. J. Appl. Earth Observ. Geoinform. 2004, 5, 29-39. [CrossRef]

7. Romero-Lankao, P.; Gnatz, D.M. Conceptualizing Urban Water Security in an Urbanizing World. Curr. Opin. Environ. Sustain. 2016, 21, 45-51. [CrossRef]

8. Narain, V. Peri-urbanization, Land Use Change and Water security: A New Trigger for Water Conflicts? IIM Kozhikode Soc. Manag. Rev. 2016, 5, 5-7. [CrossRef]

9. United Nations. Transforming Our World: The 2030 Agenda for Sustainable Development; United Nations: Paris, France, 2015.

10. World Health Organization (WHO). Water Supply, Sanitation and Hygiene Development; World Health Organization: Geneva, Switzerland, 2013; Available online: http:/ /www.who.int/water_sanitation_health/ hygiene/en/ (accessed on 21 November 2016).

11. Watkins, K. Beyond Scarcity: Power, Poverty, and the Global Water Crisis; United Nations Human Development Report: New York, NY, USA, 2006; Volume 1, p. 2.

12. Anon. 71-City Water-Excreta Survey, 2005-06; Centre for Science and Environment: New Delhi, India, 2011.

13. Basu, J. Kolkata, a Water-Rich City Turning Water-Poor, The Third Pole. 2016. Available online: https: / / www.thethirdpole.net/2015/11/11/kolkata-a-water-rich-city-turning-water-poor (accessed on 24 May 2016).

14. Pal, M.; Ghosh, S.; Mukhopadhyay, M.; Ghosh, M. Methyl mercury in fish-A case study on various samples collected from Ganges River at West Bengal. Environ. Monit. Assess. 2012, 184, 3407-3414. [CrossRef] [PubMed]

15. United Nations Environment Programme-DHI and UNEP. Transboundary River Basins: Status and Trends; United Nations Environment Programme (UNEP): Nairobi, Kenya, 2016.

16. Sengupta, C.; Sukumaran, D.; Barui, D.; Saha, R.; Chattopadhyay, A.; Naskar, A.; Dave, S. Water Health Status in Lower Reaches of River Ganga, India. Appl. Ecol. Environ. Sci. 2014, 2, 20-24.

17. Singh, R.B.; Haque, M.S.; Grover, A. Drinking water, sanitation and health in Kolkata metropolitan city: Contribution towards urban sustainability. Geogr. Environ. Sustain. 2015, 8, 64-81. [CrossRef]

18. Maplecroft. Maplecroft's 5th Annual Climate Change and Environmental Risk Atlas; Verisk Maplecroft: Bath, UK, 2016; Available online: https:/ / maplecroft.com/about/news/ccvi_2013.html (accessed on 13 October 2016).

19. Barata, M.; Ligeti, E.; De Simone, G.; Dickinson, T.; Jack, D.; Penney, J.; Rahman, M.; Zimmerman, R. Climate change and human health in cities. In Climate Change and Cities in First Assessment Report of the Urban Climate Change Research Network; Rosenzweig, C., Solecki, W.D., Hammer, S.A., Mehrotra, S., Eds.; Cambridge University Press: Cambridge, UK, 2011; pp. 179-213.

20. Mishra, T. Groundwater Scenario in Major Cities of India; Central Ground Water Board, Ministry of Water Resources, Government of India: New Delhi, India, 2011.

21. CSE. Kolkata Water Profile: City of Joy Weeps for Water; Centre for Science and Environment: New Delhi, India, 2015; Available online: http:/ / www.rainwaterharvesting.org/asp/d_feedback.htm (accessed on 13 October 2016). 
22. Diptendra, D.; Chattopadhyay, B.C. Characterization of soil over Kolkata municipal area. In Proceedings of the Indian Geotechnical Conference, Guntur, India, 17-19 December 2009; pp. 11-12. Available online: https://gndec.ac.in/ igs/ldh/conf/2009/articles/T01_03.pdf (accessed on 13 November 2017).

23. Census of India. House Listing and Housing Census Data. 2011. Available online: http:/ /www.censusindia. gov.in/2011census/hlo/HLO_Tables.html (accessed on 4 April 2018).

24. Census of India. Rural-Urban Distribution of Population (Provisional Population Totals); Government of India: New Delhi, India, 2011.

25. Wankhade, K.; Balakrishnan, K.; Vishnu, M.J. Urban Water and Sanitation: Sustaining Policy Momentum; Indian Institute for Human Settlements: Bangalore, India, 2014.

26. World Wildlife Fund (WWF). Big Cities Big Water Big Challenges. Water in an Urbanizing World; World Wide Fund for Nature, WWF: Berlin, Germany, 2011; Available online: http:/ /www.wwf.se/source.php/1390895/ Big\%20Cities_Big\%20Water_Big\%20Challenges_2011.pdf (accessed on 21 November 2016).

27. Kolkata Municipal Corporation. Kolkata Urban Sector Investment Plan; Kolkata Municipal Corporation: Kolkata, India, 2012.

28. ERDAS. ERDAS Field Guide; ERDAS LLC; Leica Geosystems Geospatial Imaging: Norcross, GA, USA, 1999.

29. Chen, C. Frontiers of Remote Sensing Information Processing; World Scientific: Singapore, 2003; p. 614.

30. Ismail, M.H.; Jusoff, K. Satellite data classification accuracy assessment based from reference dataset. Int. J. Comput. Inf. Sci. Eng. 2008, 2, 96-102. Available online: http://www.waset.org/ijcise/v2/v2-2-16.pdf (accessed on 3 July 2018).

31. Bhatta, B. Remote Sensing and GIS; Oxford University Press: New Delhi, India, 2008.

32. Bhatta, B. Analysis of urban growth pattern using remote sensing and GIS: A case study of Kolkata, India. Int. J. Remote Sens. 2009, 30, 4733-4746. [CrossRef]

33. Bhatta, B. Spatio-temporal analysis to detect urban sprawl using geoinformatics: A case study of Kolkata. In Proceedings of the 7th All India Peoples' Technology Congress, Kolkata, India, 6-7 February 2009; Forum of Scientists, Engineers \& Technologists: Kolkata, India, 2009; pp. 434-442.

34. Bhatta, B. Modelling of urban growth boundary using geoinformatics. Int. J. Digit. Earth 2009, 2, 359-381. [CrossRef]

35. Mukhopadhaya, S. Fuzzy c-means classifier with alpha-cuts in application for similarity and dissimilarity measures: A literature survey. J. Basic Appl. Eng. Res. 2016, 3, 2350-2377. Available online: https:/ / www.researchgate.net/profile/Sayan_Mukhopadhaya/publication/303880512_Fuzzy_c-Means_ Classifier_with_Alpha-cuts_in_Application_for_Similarity_and_Dissimilarity_Measures_A_Literature_ Survey/links/575a61e908ae414b8e46052e/Fuzzy-c-Means-Classifier-with-Alpha-cuts-in-Applicationfor-Similarity-and-Dissimilarity-Measures-A-Literature-Survey.pdf (accessed on 3 July 2018).

36. Narain, V. Periurban Water Security in a Context of Urbanization and Climate Change: A Review of Concepts and Relationships; Peri Urban Water Security Discussion Paper Series; Paper No. 1; SaciWATERs: Hyderabad, India, 2010.

37. Rudra, K. Water Resource and Its Quality in West Bengal; West Bengal Pollution Control Board: Kolkata, India, 2009.

38. Falkenmark, M.; Widstrand, C. Population and Water Resources: A Delicate Balance; Population Reference Bureau: Washington, DC, USA, 1992.

39. Ravell, J. Population Growth, Urbanisation and Water Security: A Case Study of Greater Brisbane; Water Supply \& Urbanization: Brisbane, Australia, 2014; Available online: https:/ / www.academia.edu/7132376/ Population_growth_urbanisation_and_water_security_A_case_study_of_Greater_Brisbane (accessed on 1 April 2018).

40. Bakker, K.; Morinville, C. The governance dimensions of water security: A review. Phil. Trans. R. Soc. A 2013, 371, 20130116. [CrossRef] [PubMed]

41. Biggs, E.M.; Duncan, J.M.A.; Atkinson, P.M.; Dash, J. Plenty of water, not enough strategy: How inadequate accessibility, poor governance and a volatile government can tip the balance against ensuring water security: The case of Nepal. Environ. Sci. Policy 2013, 33, 388-394. [CrossRef]

42. Cook, C.; Bakker, K. Water security: Debating an emerging paradigm. Glob. Environ. Chang. 2012, 22, 94-102.

43. Piesse, M. Water Security in Urban India: Water Supply and Human Health. Future Directions International, 2015. Available online: http:/ / futuredirections.org.au/wp-content/uploads/2015/09/Water_Security_in_ Urban_India_Water_Supply_and_Human_Health.pdf (accessed on 1 April 2018). 
44. Blanca, F.M. Water Security in an Urbanized World: An Equity Perspective. 2016. Available online: https: / / depositonce.tu-berlin.de/bitstream/11303/6208/3/2016_Milan.pdf (accessed on 4 June 2018).

45. Goff, M.; Crow, B. What is water equity? The unfortunate consequences of a global focus on 'drinking water'. Water Int. 2014, 39, 159-171. [CrossRef]

46. Jepson, W.; Budds, J.; Eichelberger, L.; Harris, L.; Norman, E.; O’Reilly, K.; Pearson, A.; Shah, S.; Shinn, J.; Staddon, C.; et al. Advancing human capabilities for water security: A relational approach. Water Secur. 2017, 1, 46-52. [CrossRef]

47. Bar, I.; Stang, G. Water and Insecurity in the Lavant; European Union Institute for Security Studies (EUISS): Paris, France, 2016; Available online: http:/ /www.jstor.org/stable/resrep06914 (accessed on 1 April 2018).

48. Turral, H.; Burke, J.; Faurès, J.M. Climate Change, Water and Food Security; FAO: Rome, Italy, 2011.

49. Kundu, N. Understanding Slums: Case Studies for the Global Report on Human Settlements; UN-Habitat; Earthscan: London, UK, 2003; pp. 195-228. Available online: http:/ /www.ucl.ac.uk/dpu-projects/Global_ Report/cities/kolkata.htm (accessed on 20 October 2016).

50. Roy, J.; Chattopadhyay, S.; Mukherjee, S.; Kanjilal, M.; Samajpati, S.; Roy, S. An Economic Analysis of Demand for Water Quality: Case of Kolkata. Econ. Polit. Wkly. 2004, 39, 186-192.

51. Yadav, V.; Bhagat, R.B. Spatial Dynamics of Population in Kolkata Urban Agglomeration. In Urban Development Challenges, Risks and Resilience in Asian Mega Cities; Springer: Tokyo, Japan, 2014; pp. 157-173.

52. Banerjee, A. Migration in Slums of Kolkata: Examining Migrants' Labour Market Outcomes. Working Paper for National Institute of Urban Affairs under SHRAMIC (Strengthen and Harmonize Research and Action on Migration in Indian Context) Portal. 2016. Available online: https:/ /www.niua.org/sites/default/files/ Working_paper_FINAL_VERSION.pdf (accessed on 10 May 2018).

53. Bhatta, B. Causes and Consequences of Urban Growth and Sprawl. In Analysis of Urban Growth and Sprawl from Remote Sensing Data. Advances in Geographic Information Science; Springer: Berlin, Germany, 2010.

54. Bennett, A.; Hindle, J. London Review of Books: An Anthology; Verso Books: London, UK, 1996; pp. 63-70. ISBN 1-85984-121-X.

55. World Bank. World Development Report 2009: Reshaping Economic Geography; The World Bank: Washington, DC, USA, 2009; Available online: https:/ / openknowledge.worldbank.org/handle/10986/5991 (accessed on 1 June 2017).

56. Tacoli, C.; McGranahan, G.; Satterthwaite, D. Urbanisation, Rural-Urban Migration and Urban Poverty; International Institute for Environment and Development and IOM Working Paper; International Institute for Environment and Development: London, UK, 2015.

57. Theobald, D.M. Quantifying urban and rural sprawl using the sprawl index. Presented at the Annual Conference of the Association of American Geographers, New York, NY, USA, 2 March 2001.

58. D'Souza, R.; Nagendra, H. Changes in public commons as a consequence of urbanization: The Agara Lake in Bangalore, India. Environ. Manag. 2011, 47, 840-850. Available online: https://doi.org/10.1007/s00267011-9658-8 (accessed on 12 May 2018).

59. Bhandari, L.; Gupta, A. Inputs for Health. In India Health Report 2010; Mahal, A., Debroy, B., Bhandari, L., Eds.; R.K. Books: New Delhi, India, 2010.

60. Asian Development Bank. Benchmarking and Data Book of Water Utilities in India; ADB: Mandaluyong, Philippines, 2007.

61. Guha, S. 24-hour water supply need not be a pipe dream in urban India. The Times of India; Delhi, India, 2014. Available online: http://blogs.timesofindia.indiatimes.com/plain-speak/24-hour-water-supply-neednot-be-a-pipe-dream-in-urban-india/ (accessed on 4 November 2016).

62. National Institute of Urban Affairs (NIUA). Urban Water Supply and Sanitation in Indian Cities; NIUA: New Delhi, India, 2015.

63. Ghosh, G.K. Water of India (Quality and Quantity); A.P.H. Publishing Corporation: New Delhi, India, 2002.

64. Central Pollution Control Board. Status of Water Quality in India-2011; Ministry of Environment and Forests, Government of India: New Delhi, India, 2013.

65. World Bank. India Water Supply and Sanitation-Bridging the Gap between Infrastructure and Service; The World Bank: Washington, DC, USA, 2006; Available online: http://web.worldbank.org/archive/website01291 (accessed on 1 June 2017). 
66. World Bank. Urban Water Supply in India; The World Bank: Washington, DC, USA, 2011; Available online: http:/ / www.worldbank.org/en/news/feature/2011/09/22/urban-water-supply-india (accessed on 1 June 2017).

67. Mukherjee, J.; Ghosh, A. Water Justice City Profile: Kolkata, India; The Bartlett Development Planning Unit, University College London: London, UK, 2015.

68. Chakraborti, D.; Das, B.; Rahman, M.M.; Chowdhury, U.K.; Biswas, B.; Goswami, A.; Nayak, B.; Pal, A.; Sengupta, M.K.; Ahamed, S. Status of groundwater arsenic contamination in the state of West Bengal, India: A 20-year study report. Mol. Nutr. Food Res. 2009, 53, 542-551. [CrossRef] [PubMed]

69. Segane, R. Water Management in Mega-Cities in India: Mumbai, Delhi, Calcutta, and Chennai. Water for Urban Areas, Challenges and Perspectives; United Nations University Press: Tokyo, Japan, 2000; In Big Cities Big Water Big Challenges; Water in an Urbanised World, WWF Report 2011; WWF: Germany, Berlin.

70. Sahu, P.; Sikdar, P.K. Groundwater potential zoning of a peri-urban wetland of south Bengal Basin, India. Environ. Monit. Asses. 2011, 174, 119-134. [CrossRef] [PubMed]

71. Chatterjee, R.S.; Fruneau, B.; Rudnat, J.P.; Rpy, P.S.; Frison, P.L.; Lakhera, R.C.; Dadhwal, V.K.; Saha, R. Subsidence of Kolkata (Calcutta) City, India during the 1990s as observed from space by Differential Synthetic Aperture Radar Interferometry (D-InSAR) technique. Remote Sens. Environ. 2006, 102, 176-185. [CrossRef]

72. Verburg, P.H.; van Eck, J.R.; de Hijs, T.C.; Dijst, M.J.; Schot, P. Determination of land use change patterns in The Netherlands. Environ. Plan. B Plan. Des. 2004, 31, 125-150. [CrossRef]

73. Ray, S. KMC Not to Levy Water Tax. The Times of India. 2014. Available online: https://timesofindia. indiatimes.com/city/kolkata/KMC-not-to-levy-water-tax/articleshow/45626143.cms (accessed on 30 January 2018).

74. McKenzie, D.; Ray, I. Urban Water Supply in India: Status, Reform Options and Possible Lessons. Water Policy 2009, 11, 442-460. [CrossRef]

75. Majumdar, C.; Gupta, G. Willingness to pay and municipal water pricing in transition: A case study. J. Integr. Environ. Sci. 2009, 6, 247-260. [CrossRef]

76. Beistline, H.A. Understanding the barriers of clean water access in urban slums of Kolkata, India. Christ. J. Glob. Health 2016, 3. [CrossRef]

77. Chakrabarti, C. A Sourcebook on Environment of Kolkata; Kolkata Environment Improvement Project; Kolkata Municipal Corporation: Kolkata, India, 2013.

78. Douglas, I. The Urban Environment; Edward Arnold (Publisher) Ltd.: London, UK, 1983.

79. Sau, A. A study on water supply and sanitation at a slum in Kolkata. Int. J. Med. Sci. Public Health 2017, 6, 634-638. [CrossRef]

80. SAFE-IWMI. A Report on Adi Ganga \& Wetlands: Heal the Broken Link for a Flood Resilient Kolkata. In Proceedings of the Symposium to Brainstorm Solutions for Sustainable Conservation of Wetlands \& Adi Ganga, Kolkata, India, 28 February 2017; Available online: http:/ / safeinch.org/uploads / Report\%20Symposium\%20on\%20Adi\%20Ganga\%20\&\%20Wetlands\%202017.pdf (accessed on 4 April 2018).

81. Kiran, R.; Ramachandra, T.V. Status of Wetlands in Bangalore and its Conservation aspects. ENVIS J. Hum. Settl. 1999, 16, 2-10.

82. Ali, M.; Khan, S.J.; Aslam, I.; Khan, Z. Simulation of the impacts of land-use change on surface runoff of Lai Nullah Basin in Islamabad, Pakistan. Landsc. Urban Plan. 2008, 102, 271-279. [CrossRef]

83. Hagler, B. Environmental Baseline Study of Margala and Margala North Blocks; MOL Pakistan Oil and Gas Company BV: Islamabad, Pakistan, 2007.

84. Mendoza, M.E.; Granados, E.L.; Geneletti, D.; Perez-Salicrup, D.R.; Salinas, V. Analysing land cover and land use change processes at watershed level: A multi temporal study in the Lake Cuitzeo Watershed, Mexico (1975-2003). Appl. Geogr. 2011, 31, 237-250. [CrossRef]

85. Seth, B.L. Kolkata Reconnects with Its Riverfront. Down to Earth. 2007. Available online: http://www. downtoearth.org.in/news/kolkata-reconnects-with-its-riverfront-6666 (accessed on 4 April 2018).

86. Asian Development Bank. Proposed Supplementary Loan India: Kolkata Environmental Improvement Project; ADB: Kolkata, India, 2006.

87. Palit, A.; Batabyal, P.; Kanungo, S.; Sur, D. In-house contamination of potable water in urban slum of Kolkata, India: A possible transmission route of diarrhea. Water Sci. Technol. 2012, 66, 299-303. [CrossRef] [PubMed] 
88. Buyadi, S.N.A.; Wan Mohd, W.M.N.; Misni, A. Impact of land use changes on the surface temperature distribution of area surrounding the National Botanic Garden, Shah Alam. Proc. Soc. Behav. Sci. 2013, 101, 516-525.

89. Haque, M.S.; Singh, R.B. Air Pollution and Human Health in Kolkata, India: A Case Study. Climate 2016, 5, 77. [CrossRef] 